\title{
PROFIL PASIEN KO-INFEKSI TUBERCULOSE-HIV DI RSUD DOK II JAYAPURA Tuberculosis-HIV Co-infection Profile in DOK II Hospital Jayapura
}

\author{
Elfride Irawati ${ }^{1}$, Rusnaeni ${ }^{1}$ \\ ${ }^{1}$ Fakultas Biologi, Universitas Cenderawasih Papua \\ E-mail : ira_sianturi@yahoo.co.id
}

\begin{abstract}
Abstrak
Papua adalah daerah yang memiliki angka prevalensi HIV-AIDS tertinggi di Indonesia. Infeksi TB adalah infeksi oportunistik terbanyak yang menyerang pasien HIV-AIDS. Tujuan penelitian ini adalah untuk mengetahui profil pasien koinfeksi TB-HIV yang mendapatkan pengobatan obat anti tuberculosis (OAT) di klinik VCT RSUD Dok II Jayapura selama periode Januari 2011 hingga September 2012. Penelitian ini merupakan penelitian retrospektif deskriptif. Data diambil dari rekam medik, kartu TB 01 dan hasil mikrobiologis pasien koinfeksi TB-HIV yang mengambil OAT di klinik VCT RSUD Dok II Jayapura. Hasil penelitian menunjukkan bahwa 35 dari 124 pasien adalah pasien default yang mengalami efek samping obat dan tidak memiliki Pengawas Minum Obat (PMO). Efek samping obat TB menjadi kendala selama pengobatan sehingga peranan PMO yang berasal dari keluarga inti mampu membantu pasien menyelesaikan pengobatan TB tersebut.
\end{abstract}

Kata kunci: AIDS, pengawas minum obat (PMO), rifampisin, tuberculosis,

\begin{abstract}
Papua shows the highest prevalency rate of HIV-AIDS in Indonesia and almost 60\% people who live with HIV develop tuberculosis (TB), hence TB is the most common opportunistic infection in HIV patients. This study was aimed to know and to describe the profile of TB-HIV co-infection patients among TB patients according to clinical symptoms and the side effects of FDC (Fixed Dose Combination) drugs. Methods used was descriptive study taken from medical record of 124 TB-HIV co-infection patients in Dok II Jayapura hospital, Papua during January 2011 - September 2012. Results showed that 35 of 124 patients indicated side effect of antituberculosis risk default when they did not undergo drug monitoring therapy. The patients should be controlled by his/her family to help them through all the side effects of antituberculose drugs to complete the treatment.
\end{abstract}

Keywords: AIDS, drug monitoring therapy, rifampicin, tuberculosis

\section{PENDAHULUAN}

Tuberkulosis (TB) adalah penyakit yang sampai saat ini menjadi masalah dunia dan secara geografis di Asia dan Afrika angka penularan tuberkulosis masih menjadi masalah besar. Asia menjadi benua yang memiliki populasi penduduk terbanyak yang terinfeksi TB dengan Cina, India serta Indonesia menyumbang hampir $40 \%$ lebih dari kasus TB di seluruh dunia. Afrika menjadi daerah dengan angka populasi $24 \%$ kasus dunia serta angka kematian tertinggi untuk penyakit tersebut. Hal ini menjadi semakin mengancam ketika kasus HIV-AIDS dan MDR (Multi Drug Resistance) TB menambah kompleksnya situasi yang ada sekarang.

Indonesia sendiri menurut WHO tahun 2011 dinyatakan sebagai negara nomor 3 yang memiliki penduduk dengan penyakit TB terbanyak didunia dengan angka sebesar 242326 orang. Hal ini semakin diperparah dengan angka penemuan pasien Human Imunnodeficiency Virus (HIV) yang selalu meningkat mengingat bahwa hampir $60 \%$ pasien HIV akan mendapatkan TB sebagai infeksi oportunistik.
Menurut laporan dari Ditjen PP \& PL Kemenkes RI, pada tahun 2012 didapat bahwa jumlah pasien HIV 21511 orang dan jumlah pasien AIDS 5686 orang. Provinsi Papua sesuai dengan data yang dilansir peroleh bahwa pasien HIVsebanyak 10113 orang dan pasien HIVsebanyak 7795 orang. Angka prevalensi penularan HIV untuk Papua 2,75\% diatas angka prevalensi penularan HIV nasional yang sebesar $0,18 \%$. Melihat data ini dapat disimpulkan bahwa angka prevalensi penularan HIV di Papua lebih tinggi dibandingkan dengan angka penularan HIV nasional sehingga kemungkinan angka kasus penemuan TB di Papua akan semakin meningkat seiring dengan angka penularan HIV yang juga meningkat.

Infeksi HIV akan meningkatkan risiko reaktivasi infeksi laten TB dan meningkatkan risiko sakit TB setelah terinfeksi atau reinfeksi oleh TB. Hal lain yang menjadi masalah besar infeksi HIV akan mengubah perjalanan klinis TB. Masalah ini semakin diperburuk dengan angka default yang merupakan terjadinya kegagalan pengobatan yang berpotensi meningkatkan kemungkinan terjadinya resistensi terhadap obat anti 
TBC. Resistensi yang akan terjadi akan mengakibatkan penambahan biaya pengobatan yang lebih besar dan waktu yang lebih lama sehingga produktivitas penderita TB paru dewasa diperkirakan akan kehilangan rata-rata waktu kerjanya 3 sampai 4 bulan dan hal ini akan mengakibatkan penderita tersebut kehilangan pendapatan tahunan rumah tangganya sekitar 20-30\%..

Adanya PITC (Provider Initiated Testing and Counseling) yang dilakukan di polik rawat jalan dan rawat inap untuk semua kasus suspek TB di RSUD Dok II Jayapura telah dilakukan dan didapatkan angka penemuan kasus dan pasien yang cukup besar. Fokus terhadap pasien koinfeksi TB HIV dalam menjalani terapi Obat Anti Tuberculose (OAT) di RSUD Dok II ini menjadi dasar penelitian ini . Hal ini menjadi dasar mengapa perlunya untuk mengetahui profile pasien koinfeksi TB HIV di RSUD Dok II sebagai rumah sakit rujukan untuk pasien TB dan HIV di Papua dan Papua Barat selama Januari 2011 sampai September 2012 .

\section{METODE}

Desain penelitian: Penelitian ini merupakan penelitian deskriptif retrospektif dengan analitik observasional serta menggunakan data sekunder (rekam medis poliklinik paru RSUD Dok II Jayapura)

Lokasi penelitian: Klinik VCT RSUD Dok II Jayapura

Waktu penelitian: Penelitian dilakukan mulai Juli sampai dengan Agustus 2013

Populasi : Seluruh pasien rawat jalan yang menderita penyakit tuberkulosis yang berkunjung ke klinik VCT RSUD Dok II Jayapura terhitung tanggal Januari 2011 sampai dengan September 2012

Pengambilan data: Data diambil secara retrospektif melalui rekam medis klinik, kartu TB 01 dan data laboratorium mikrobiologi di klinik VCT RSUD Dok II Jayapura dalam kurun waktu Januari 2011 sampai September 2012. Data kemudian diolah dan dianalisis menggunakan program komputer perangkat lunak SPSS 17 dan ditampilkan dalam bentuk tabel dan dianalisis secara deskriptif.

\section{HASIL DAN PEMBAHASAN}

Pasien TB yang terjaring tahun Januari 2011 sampai September 2012 adalah 329 pasien dengan pasien koinfeksi TB HIV adalah 164 orang. Pada penelitian ini hanya digunakan 124 pasien sebagai sampel yang diharapkan dapat mewakili semua populasi pasien koinfeksi TB HIV di RSUD Dok II Jayapura. Sampel yang diambil dari rentang waktu tersebut adalah 124 pasien dengan pasien koinfeksi TB HIV sebanyak 61 pasien $(49,2 \%)$ adalah laki-laki sedangkan pasien perempuan sebanyak 63 pasien $(50,8 \%)$ dengan umur pasien 100 $\%$ merupakan umur produktif yaitu antara 14 tahun sampai umur 54 tahun dengan faktor resiko penularan $100 \%$ dari penularan hubungan seksual yang berisiko. Data yang didapat memperlihatkan hasil sebagai berikut:
Tabel 1. Profil Gambaran Umum Pasien Koinfeksi TB HIV di Klinik VCT RSUD Dok

II Jayapura Periode 2011 -2012 (n=124)

\begin{tabular}{|c|c|c|}
\hline $\begin{array}{l}\text { Variabel } \\
\text { Penelitian }\end{array}$ & $\mathrm{N}=124$ & $\begin{array}{c}\text { Persenta } \\
\text { se (\%) }\end{array}$ \\
\hline \multicolumn{3}{|l|}{ Jenis Kelamin } \\
\hline Laki-laki & 61 & $49,2 \%$ \\
\hline Perempuan & 63 & $50,8 \%$ \\
\hline \multicolumn{3}{|c|}{ Rentang Umur Pasien } \\
\hline $15-<55$ tahun & 124 & $100 \%$ \\
\hline$>55$ tahun & & \\
\hline \multicolumn{3}{|c|}{ Efek Samping Obat (ESO) } \\
\hline ESO & 54 & $42,7 \%$ \\
\hline Non ESO & 70 & $57,3 \%$ \\
\hline \multicolumn{3}{|c|}{ Pendamping Minum Obat (PMO) } \\
\hline PMO & 65 & $52,4 \%$ \\
\hline Non PMO & 59 & $47,6 \%$ \\
\hline \multicolumn{3}{|l|}{ Klasifikasi TB } \\
\hline TB Paru & 74 & $59,7 \%$ \\
\hline TB Extra Paru & 50 & $40,3 \%$ \\
\hline \multicolumn{3}{|l|}{ Rentang CD4 } \\
\hline$<200$ & 112 & $90 \%$ \\
\hline$>200$ & 12 & $10 \%$ \\
\hline
\end{tabular}

Nilai CD4 adalah angka standard sebagai penentuan progress penyakit HIV pada pasien yang terinfeksi. Nilai $\mathrm{CD}_{4} \leq 200$ adalah yang ditemukan pada pasien koinfeksi TB- HIV adalah 112 pasien (90\%) dan hanya 12 pasien (10\%) dari sampel yang memliki $C D_{4} \geq 200$. Jumlah $C_{4}$ yang semakin rendah mengindikasikan kekebalan tubuh yang semakin menurun sehingga patogen penyebab infeksi dapat masuk ke dalam tubuh secara bersama-sama.

Tabel 2. Jenis Keluhan dari Pengaruh Efek Samping OAT Pada Pasien TB HIV Periode 2011-2012 Di RSUD Dok II Jayapura

\begin{tabular}{|r|l|r|}
\hline No & Jenis Keluhan & \multicolumn{1}{|c|}{ Prosentase (\%) } \\
\hline 1 & Kesemutan/kram & $\mathbf{2 0 , 4 \% ( 2 )}$ \\
\hline 2 & Hepatitis & $\mathbf{2 , 2 \% ( 8 )}$ \\
\hline 3 & Pusing & $4,5 \%(7)$ \\
\hline & anemia & $12,5 \%(5)$ \\
\hline 4 & hemolitik & $16 \%(4)$ \\
\hline 5 & gatal-gatal & $6,8 \%(6)$ \\
\hline 6 & Sesak & $\mathbf{1 7 \% ( 3 )}$ \\
\hline 7 & Mual & $\mathbf{2 0 , 6 \% ( 1 )}$ \\
\hline 8 & Demam
\end{tabular}

Efek samping OAT dialami oleh pasien koinfeksi TB HIV dengan $\mathrm{CD}_{4} \leq 200$ sekitar 54 pasien mengalami efek samping sedangkan untuk pasien koinfeksi TB HIV memiliki CD4 $\geq 200$ ternyata 8 pasien tersebut mendapatkan ESO selama pengobatan TB yang dilakukannya. 
Pasien koinfeksi TB HIV yang mendapatkan pengobatan di klinik VCT RSUD Dok II Jayapura selama Januari 2011 sampai September 2012 sebanyak 164 pasien dari jumlah keseluruhan sebanyak 329 pasien TB yang terjaring periode tersebut. Hampir $90 \%$ pasien HIV yang menjadi sampel penelitian memiliki rentang $C D \leq 200$ ternyata juga terinfeksi dengan TB hal ini sesuai dengan penelitian sebelumnya yang mengatakan bahwa semakin menurunnya $\mathrm{CD}_{4}$ seorang pasien maka semakin mudah pula orang tersebut terinfeksi TB $^{7}$ Melihat angka penemuan TB pada pasien HIV memberikan korelasi bahwa angka TB yang ada pada saat tersebut sebagian besar adalah pasien HIV yang terinfeksi pula dengan TB sehingga semakin besarnya angka penemuan HIV maka akan semakin besar pula angka penularan TB di Papua.

Epidemi HIV merupakan ancaman serius bagi pengendalian TB di Indonesia serta bagi para klinisi hal ini terjadi karena gambaran klinis TB pada penderita HIV sering tidak khas dan sangat bervariasi sehingga diagnosis menjadi sulit. Efek samping OAT pun lebih sering terjadi pada pasien HIV daripada non HIV. Tuberkulosis pada pasien dengan $\mathrm{CD}_{4}$ yang rendah dihubungkan dengan gejala klasik TB yang jarang, lebih banyak gejala sistemik seperti demam, lemah ,kesemutan, mual, anemia dan lesu. Hal ini sesuai dengan efek samping obat kategori I yang umum digunakan yaitu isoniasid, rifampisin dan pyrazinamide. Hal inilah yang perlu diperhatikan para praktisi kesehatan untuk menjaga agar pasien diminimalkan untuk menjadi pasien default karena adanya efek samping obat yang dirasakan oleh pasien .

Angka penemuan TB extra paru ternyata ditemukan 50 pasien $(40,3 \%)$ dari sampel 124 pasien yang masuk dalam sampel penelitian ini. Kejadian TB Extra paru banyak dikaitkan dengan HIV dan hal ini sesuai dengan penelitian yang mengatakan bahwa ras dan infeksi HIV memiliki keterkaitan dengan angka kejadian Extra paru.

Kehadiran HIV dengan kondisi sistem pertahanan tubuh yang menurun akan mempercepat terjadinya infeksi dan memperpanjang periode infeksi TB yang berujung pada manifestasi TB-MDR ${ }^{3.4}$ hal inilah yang perlu diantisipasi karena angka default pun dapat memberikan sumbangan terhadap kasus TB -MDR (Multi Drug Resistance) yang terjadi salah satu sebabnya adalah pemberian terapi TB yang tidak adekuat akan menyebabkan mutants resisten. Hal ini amat ditakuti karena akibat kegagalan ini bukan hanya merugikan pasien tetapi juga meningkatkan penularan pada masyarakat. TB resistensi obat anti TB (OAT) pada dasarnya adalah suatu fenomena buatan manusia, sebagai akibat dari pengobatan pasien TB yang tidak adekuat yang menyebabkan terjadinya penularan dari pasien TB-MDR ke.orang lain.

Pada tabel diatas dapat dilihat bahwa pasien yang banyak mengalami efek samping obat terbanyak adalah mereka yang termasuk pada pasien dengan klasifikasi pasien sembuh dan lengkap yang memiliki PMO (Pendamping Minum Obat). Hal berarti dengan adanya
PMO yang biasanya berasal dari keluarga inti seperti ibu, suami, istri dan anak dapat memberikan arti keberhasilan dalam pengobatan TB. Terlihat pada tabel diatas bahwa banyaknya efek samping obat dapat saja terjadi pada kelompok pasien sembuh dan lengkap serta pasien default sama-sama mengalami efek samping obat tetapi adanya PMO pada kelompok yang diamati memberikan hasil pengobatan yang lain.

$\mathrm{Hal}$ ini sesuai dengan penelitian sebelumnya yang mengatakan bahwa sebaiknya PMO adalah berasal dari keluarga inti dan berada dalam rumah yang sama sehingga memilki waktu untuk melihat dan memperhatikan pasien dalam meminum obat TB tersebut $^{8}$.

Peran PMO yang mampu membantu pasien dalam menghadapi ESO dalam pengobatan TB terbukti mampu menjadi faktor penentu keberhasilan pengobatan tersebut. Hal ini dapat dipahami bahwa pasien yang memiliki PMO akan lebih sering datang ke pelayanan kesehatan sehingga jika efek samping OAT muncul maka peran PMO akan memberikan dukungan dalam melewati masa-masa ESO yang tidak menyenangkan tersebut. Hasil tersebut sesuai dengan penelitian yang pernah dilakukan menemukan bahwa penderita yang memiliki PMO bukan dari anggota keluarga berisiko tidak patuh sebesar 3,2 kali dibandingkan dengan penderita TB Paru dengan PMO yang berasal dari anggota keluarga dan menemukan bahwa penderita TB yang merasa tidak cukup mendapat dukungan keluarga mempunyai risiko 2 kali lebih besar untuk mengalami default.

Angka default ini dapat memberikan sumbangan terhadap kasus TB-MDR (Multi Drug Resistance) yang terjadi salah satu sebabnya adalah pemberian terapi TB yang tidak adekuat akan menyebabkan mutants resisten. Hal ini amat ditakuti karena akibat kegagalan ini bukan hanya merugikan pasien tetapi juga meningkatkan penularan pada masyarakat. TB resistensi obat anti TB (OAT) pada dasarnya adalah suatu fenomena buatan manusia, sebagai akibat dari pengobatan pasien TB yang tidak adekuat yang menyebabkan terjadinya penularan dari pasien TBMDR ke orang lain.

\section{SIMPULAN}

Pasien koinfeksi TB HIV lebih banyak menyerang pada mereka yang memiliki $\mathrm{CD}_{4} \leq 200$ dan TB Extra paru lebih banyak ditemukan pada pasien koinfeksi TB HIV di RSUD Dok II Jayapura selama periode Januari 2011 sampai September 2012. Efek samping obat yang terjadi selama pengobatan OAT dapat menjadi masalah yang dapat mengakibatkan kegagalan dalam pengobatan TB tetapi hal ini dapat dikurangi bila selama pengobatan OAT ini pasien selalu didampingi oleh PMO yang berasal dari keluarga inti yang mampu membantu pasien dalam melewati masa sulit selama pengobatan dilakukan. 


\section{UCAPAN TERIMA KASIH}

Ucapan terimakasih kepada LEMLIT Universitas Cenderawasih yang telah membiayai penelitian ini dari awal sampai akhir penelitian ini selesai dikerjakan.

\section{PUSTAKA}

1. Kipp AM, Stout JE, Hamilton CD, Van Rie A. 2008. 'Extrapulmonary Tuberculosis. Human Immunodeficiency Virus, and Foreign Birth in North Carolina, 1993-2006'. BMC Public Health 2008, 8:107. Disitasi: 1 Juni 2010 dari: http://www.biomedcentral.com/147-2458/8/107

2. Fiske $C T$, Griffin MR, Erin H, Warkentin J, Lisa $K$, Arbogast PG, Sterling TR. 2010. 'Black Race, Sex, and Extrapulmonary Tuberculosis'. BMC Infectious Disease 2010, 10:16. Disitasi: 1 Juni 2010 dari: http://www.biomedcentral.com/147-2334/10/16

3. Soepandi PZ. Diagnosis dan faktor yang mempengaruhi terjadinya TB-MDR. Jakarta: Departemen Pulmonologi \& Ilmu kedokteran Respirasi FKUI-RS Persahabatan; 2008.

4. Tulak A, Hudoyo A, Aditama TY. Pengobatan TBMDR dengan ofloksasin. Jurnal Tuberkulosis Indonesia. 1999; 4: 14-8.
5. Syaumaryadi, 2001. Hubungan Keluhan Efek Samping Obat Anti Tuberkulosis dengan Ketidakpatuhan Berobat Penderita TB Paru di Kota Palembang tahun 1999-2000. Program Pasca Sarjana IImu Epidemiologi Kekhususan Epidemiologi Lapangan, Fakultas Kesehatan Masyarakat, Universitas Indonesia, 2001

6. Xiangin $\mathrm{Ai}$, et al. Factors associated with low cure rate of tuberculosis in remote poor areas of shaanxi Province, China: a case control study.Biomedcentral, 2010. Artikel asli dapat diakses pada http://www.biomedcentral.com/14712458/10/112

7. Diedrich C.R , Flynn. J.L, 2011, HIV-1/Mycobacterium tuberculosis Coinfection Immunology: How Does HIV-1 Exacerbate Tuberculosis, Infection and Immunity Apr. 2011, p. 1407-1417 Vol. 79, No. 4 Artikel asli dapat diakses pada http://iai.asm.org/on June 2013

8. Purwanta, 2005 , Ciri-Ciri Pengawas Minum Obat yang Diharapkan Oleh Penderita Tuberkulosis Paru Di Daerah Urban dan Rural, JMPK Vol. 08/No.03/September/2005 Yogyakarta 